\title{
Kopjafaállítás Semmelweis Ignác tiszteletére - Erdélyben
}

A magyar kormány úgy döntött, hogy 2018-at Semmelweis-emlékévvé nyilvánítja. Az emlékévhez kapcsolódóan számos rendezvény zajlott Magyarországon és külföldön is. Ezek közül csak néhányat említünk meg: a berlini magyar nagykövetségen május 25-én külföldi professzorok részvételével egynapos emlékülés volt (szoboravatásra is sor került); Révkomáromban, a Szlovákiai Magyar Egészségügyi Társaság (SZMET) a Selye János Egyetem társszervezésével június 9-én, a VI. Arányi Lajos Napok keretében szervezett nemzetközi konferenciát, szobor és az újonnan megnyíló Semmelweis Ignác Egészség Központ (Zdravcentrum) avatásával. Budapesten június 13án Semmelweis Ignác emlékkötetének a bemutatására került sor, a kötethez Semmelweis életéról szóló 1938-as filmet tartalmazó DVD-t csatoltak; Győrben június 26án tartottak megemlékezést. A Semmelweis Emlékbizottság június 30-án nagyszabású rendezvény keretében, nemzetközi részvétel mellett tartotta megemlékezését, és egyúttal szobrot is avattak Semmelweis tiszteletére.

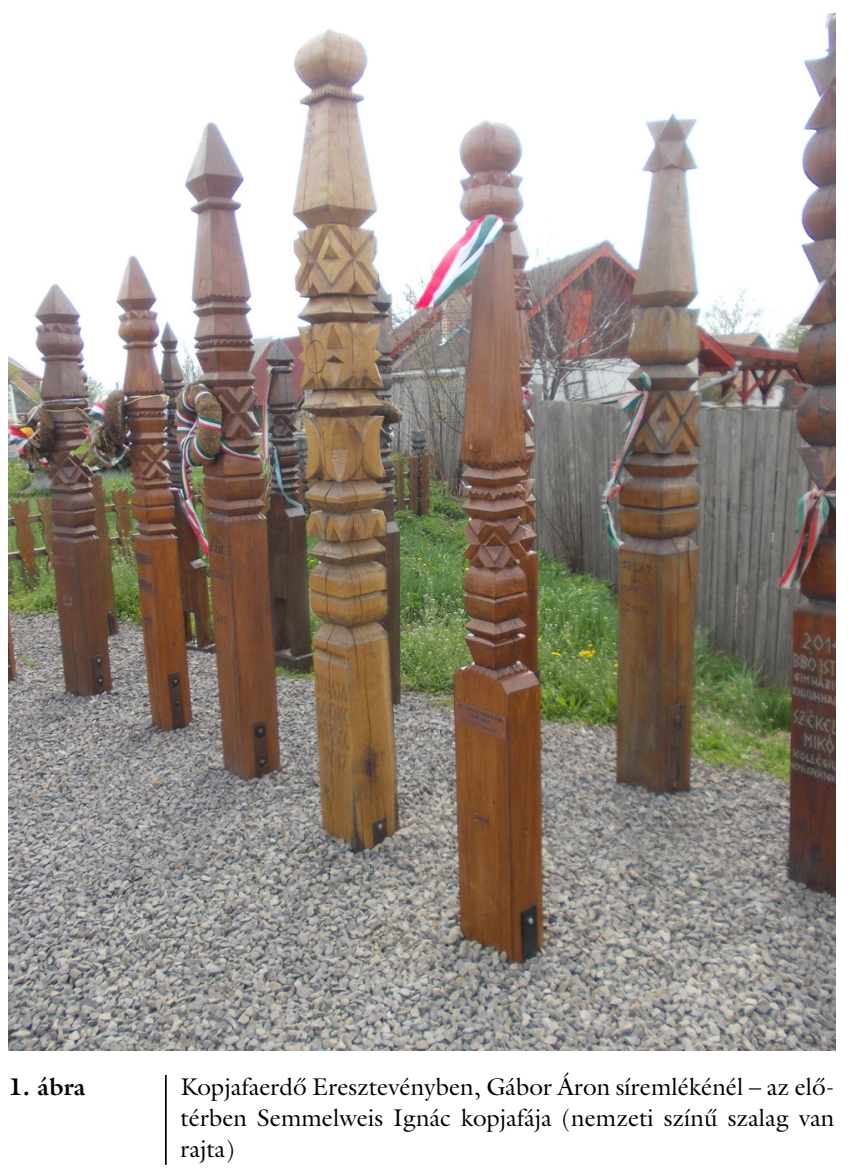

Az Orvosi Hetilap Szerkesztősége a lap 26. számát teljes egészében Semmelweis Ignác emlékének adózva szerkesztette.

Mi (e cikk szerzője és felesége, dr. Vincze-Tiszay Gabriella), úgy döntöttünk - még 2017-ben -, hogy Semmelweis Ignác emlékére kopjafát állítunk - Erdélyben.

A magyar népi hagyományok szerint a kopjafa jelkép. A jelképeknek információközvetítő szerepük van, amelyet dekodifikálunk, illetve életünk folyamán tanulással megtanuljuk, elsajátítjuk ezt a speciális múveletet. Hogyha érzékeljük, hogy más emberrel „egy hullámhosszon” gondolkozunk, tehát hasonló jellemzői vannak, mint nekünk, hasonlóan gondolkodik, viselkedik, érzékel szóban és tettben, akkor mint rokonlelkeknél, az empátia és az együttérzés lelki folyamata kezdetét veheti. Az együttgondolkodók számára azért van jelentősége a kopjafák állításának, mert a rokonlelkek akkor is virtuálisan érzik egymást, ha csak az egyik fél van jelen és látja a kopjafát.

A modern embernek is szüksége van egy egészséges egyensúly megteremtésére az anyagi és a szellemi világ jelképei között. A harmonikus egyensúly akkor jön létre, ha az általa használt jelkép másoknak is hasonlóan üzen. A kopjafákat gondozni kell, hogy több évtizeden keresztül álljanak és üzenjenek a mellettük elhaladó vándoroknak.

Semmelweis Ignác kopjafáját Erdélyben, Eresztevényben, a Gábor Áron síremléke melletti kopjafaerdőben avattuk fel 2018. május 20-án, Pünkösdvasárnap. A kopjafaavatás szertartásán beszédet mondott Maksa (jelen-

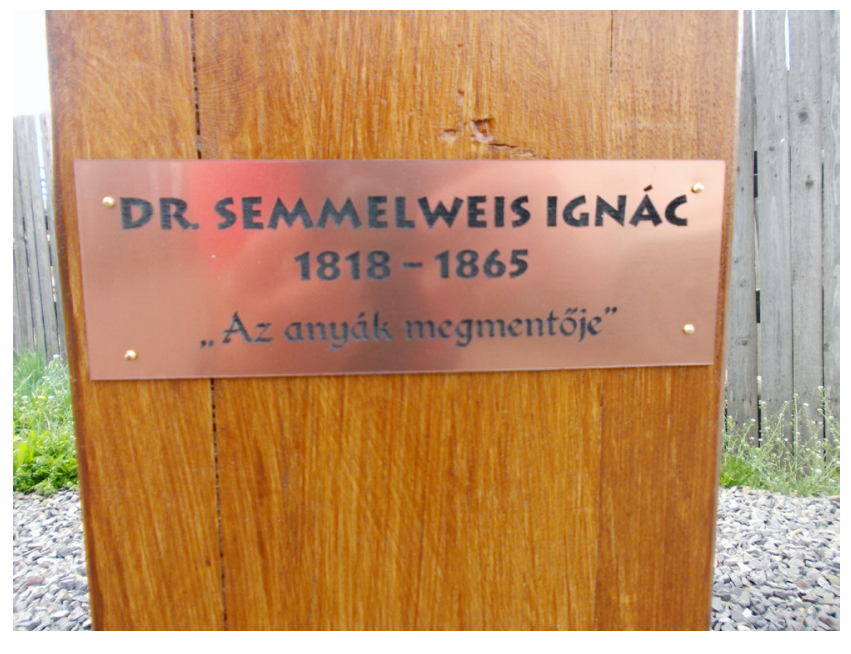

2. ábra

| Semmelweis Ignác kopjafájának réztáblája 
leg közigazgatásilag Eresztevény Maksához tartozik) polgármestere, Deszke János, aki a kopjafaerdő jelentőségéről, a nemzeti kegyelethely új formát öltő hagyománnyá válásáról, a nemzeti szimbólumok jelentőségérooll beszélt. A kopjafát Balázs Antal kopjafafaragó mester készítette, aki mondanivalójában kihangsúlyozta a kopjafák modern kori üzenetét.

Prof. Dr. Vincze János - Budapestről - beszédében hangsúlyozta e két, a XIX. század közepén élt magyar zseni lelki hasonlóságait, mert mindketten - a végsőkig - hittek saját találmányukban-felfedezésükben: Gábor Áron az általa készített ágyúk hatékonyságában, Semmelweis Ignác a szülőszoba és a nőgyógyász orvos kezének extrém tisztaságában. Hasonlóan a saját találmá- nyuk-felfedezésük okozta a halálukat is: Gábor Áront ágyúgolyó sebesítette halálra, Semmelweis Ignác halálát egy véletlen fertőzés okozta.

A maksai férfidalárda 1848-as dalokat adott elő, az éneklésbe az ünneplő közönség is bekapcsolódott. Mứvészek - hegedún és tárogatón - XIX. századi dallamokat játszottak. A helyi iskola végzős diákjai a szavalataikat nagy átéléssel adták elő. A négy magyar történelmi egyház jelen lévő képviselői megáldották a felszentelt kopjafákat, és koszorúzás után a magyar és a székely himnusz eléneklésével zárult az ünnepség.

Vincze János $d r$.

\section{PÁLYÁZAT}

A Prof. Dr. Romics László Akadémikus Emlékére Alapítvány pályázatot hirdet Magyarországon dolgozó, magyar állampolgárságú, 40 éven aluli orvosok és orvosbiológiai kutatással foglalkozó személyek számára. A nyertes pályázó(k) között 500000 Ft alapítványi adomány kerül kiosztásra.

A pályázat célja: a klinikai gyógyítás vagy orvosi tudományos kutatás területén dolgozók kiemelkedő tudományos tevékenységének elismerése.

Előnyt élveznek azok a pályázók, akik az alapítvány névadójának munkásságát folytatva cardiovascularis és anyagcsere-betegségek területéről nyújtanak be pályázatot.

A pályázat benyújtásának határideje: 2019. január 31. (elbírálásának határideje: 2019. április 30.)

A pályázatot a palyazat@romicsalapitvany.hu e-mail címre pdf formátumban kell benyújtani.

A pályázatot természetes személy, saját nevében, magyar nyelven nyújthatja be, a pályázati anyag ábrák nélkül maximum 15000 leütés (karakter) terjedelmű lehet. A pályázathoz mellékelni kell egy rövid szakmai életrajzot a születési év megjelölésével.

A pályázat benyújtását saját kézzel aláírt és dátummal ellátott levélben kell bejelenteni az alapítvány titkárának címezve (a borítékra írandó cím: dr. Dudás Márta, 1461 Budapest, Pf 62.) könyvelt (ajánlott) küldeményben, mert ezen bejelentés alapján válik hitelessé a pályázat. A pályázatot nyomtatott formában nem kell mellékelni.

Az alapítvány adatairól, működéséről a www.romicsalapitvany.hu honlapon található információ. 